\title{
METODOLOGI TAFSIR FAKHRU AL-DIN AL-RAZI: Telaah Tafsir QS. Al-Fatihah dalam Mafatih al-Ghayb
}

\author{
Anas Shafwan Khalid \\ Mahasiswa Pascasarjana UIN Syarif Hidayatullah Jakarta \\ anassafwankhalid@gmail.com
}

\begin{abstract}
The interpretive methodology is closely related to the background of the exegete. Tafsir Mafatih al-Ghayb by Fakhruddin Al-Razi proves this conclusion. He comes from the Ash'ariyah-Syafi'iyah. The style and the interpretation tools he uses in this work is very strong with the study of kalam, linguistic aspects and legal-fiqh side. The distinguishing characteristic of earlier scholars is its status as the final generation of tariqat al-muta'akkhirin, which colored his work with philosophical studies, mysticism and Aristotelian logic.
\end{abstract}

\begin{abstract}
Abstrak
Metodologi tafsir berhubungan erat dengan latar belakang si mufassir. Tafsir Mafatih al-Ghayb karya Fakhruddin Al-Razi membuktikan kesimpulan ini. Ia berasal dari kalangan Asy'ariyah-Syafi'iyah. Corak dan perangkat tafsir yang ia gunakan dalam karya ini sangat kental dengan kajian kalam, aspek kebahasaan dan sisi legal-fiqh. Karakteristik yang membedakan dari ulama sebelumnya adalah statusnya sebagai generasi akhir tariqat al-muta'akkhirin, yang mewarnai karyanya dengan kajian filsafat, tasawuf dan logika Aristotelian.
\end{abstract}

Keywords: tafsir bi ar-ra'y, tariqat al-muta'akkhirin, mantiq, asy'ariyah 


\section{A. Pendahuluan}

Sebuah proses membaca tidak akan terlepas dari dua hal, latar belakang pembaca dan latar belakang situasi. ${ }^{1} \quad$ Latar belakang pembaca mengarahkannya memaknai objek dengan kebenaran-kebenaran yang ia yakini, baik dalam pengertian menjadikan latar belakang itu sebagai ibngkai pemaknaan, atau justru menjadikan objek sebagai pembenaran bagi keyakinan-keyakinanya. Sementara situasi di sekitar proses membaca merupakan kenyataan yang menuntut pembaca untuk bersikap terhadap objek. Dengan begitu, proses pembacaan secara tidak sadar diarahkan untuk memecahkan problem yang dihadapi pembaca.

Demikian juga kita membaca proses penafsiran dan segenap produknya. Seorang mufassir adalah anak zaman yang dididik dalam kultur epistemologis tertentu, dengan rangkaian sanad keilmuan yang baku dan keyakinan-keyakinan yang berbeda dari kultur epistemologis lainnya. Begitu pun ia lahir dan tumbuh dalam situasi sosial-politik dan fase perkembangan keilmuan pada zamannya. Ia adalah anak zaman, bisa dipastikan berbeda dari zaman sebelum dan setelahnya.

Dalam kerangka seperti inilah penulis akan mengulas metode penafsiran Fakhruddin Al-Razi, yang dibatasi pada karyanya Mafatih al-

1 Muhammad 'Abid al-Jabiri. 1993. Nahnu wa 1-Turath Qira'at Mu'asirah fi Turathina al-Falsafi. Bayrut: Markaz Tsaqafi 'Arabi. hlm. 22.
Ghayb atau Tafsir al-Kabir, dan secara spesifik akan membedah tafsir QS. AlFatihah yang memakan 1 jilid dari 32 jilid yang tersedia. Meski, terdapat beberapa pendapat bahwa al-Razi wafat sebelum karya ini diselesaikan. ${ }^{2}$

\section{B. Al-Razi dan Generasi Muta'akkhirin}

Fakhruddin Al-Razi merupakan julukan bagi Muhammad ibn 'Umar ibn Husayn ibn Hasan ibn 'Ali, seorang ulama Shafi'iyyah dan Ash'ariyyah yang lahir pada $544 \mathrm{H} / 1149 \mathrm{M}$ di kota Ray, Iran. Sedang wafatnya pada 606 H/1209 M. ${ }^{3}$

Ia lahir dan tumbuh dalam keluarga ulama. Ayahnya, Diya'uddin 'Umar, adalah salah seorang ulama madzhab Syafi'i sekaligus ulama dalam ilmu kalam dari mazhab Asy'ariyah. Silsilah keilmuannya bersambung dengan Imam Shafi'i melalui jalur alMuzanni, melalui 'Ali Abi Qasim alAnmati, dari Abi 'Abbas ibn Surayj, dari Abu Ishaq al-Murwazi, dari Abu Zayd al-Murwazi, al-Qaffal alMurwazi, dari Husayn al-Murwazi dan al-Farra' al-Baghawi. Sementara silsilah ilmu kalamnya diterima dari Sulayman ibn Nasir al-Ansari, yang merupakan

2 Faktor ini menjadi salah satu pertimbangan penulis memilih jilid pertama sebagai objek penelitian. Sebab, dalam riwayat yang kuat, Al-Razi hanya menafsirkan sampai QS. Al-Anbiya' (sampai jilid 22) sedang sisanya dituntaskan oleh Shihabuddin al-Khuwi (w. 637 $\mathrm{H}$, murid al-Razi) dan Najmuddin al-Qumuli (w. $727 \mathrm{H}$ ). Dalam riwayat lain, al-Khuwi yang menuntaskan Mafatih al-Ghayb, sedang alQumuli membuat karya lain yang melengkapi tafsir ini. Muhammad Husayn al-Dhahabi. 2010. al-Tafsir wa al-Mufassirun. J.I, Kuwayt: Dar al-Nawadir. hlm. 291.

3 Khadijah Hammadi Abdallah. 2012. Manhaj al-Imam Fakhruddin Al-Razi, Bayna alAsya'irah wal Mu'tazilah. Bayrut: Dar alNawadir. hlm. 32. 
murid dari al-Juwayni (guru Imam alGhazali), bersambung pada Abu Ishaq al-Isfirayini, $\mathrm{Abu}$ Hasan al-Bahili hingga Abu Hasan al-Asy'ari. ${ }^{4}$

Ketokohan ayahnya membuat AlRazi nyaris tidak berguru kepada orang lain. $^{5}$ Ia tumbuh menjadi seorang Syafi'iyyah-Asy'ariyyah. Setelah ayahnya wafat, baru dia berguru kepada Kamaluddin as-Simnani (Murid imam al-Baqillani) dan Majduddin al-Jili (murid imam al-Ghazali). ${ }^{6}$

Rentang kehidupan Al-Razi berada pada masa kemunduran Daulah Bani Abbas, dan awal munculnya dinasti-dinasti. Sedang dalam konteks sejarah pemikiran ia berada pada kultur perdebatan antara kalangan rasionalis dan tradisionalis, di mana ia tampil sebagai kritikus handal dan terlibat dalam perdebatan dengan ulama-ulama sezamannya. Di antara tokoh-tokoh yang hidup di masa itu adalah Sayfuddin Al-Amidi [w. $631 \mathrm{H}$ ], 'Izzuddin Ibn Abdissalam [w. $660 \mathrm{H}$ ], Ibn Rushd [w. 595 H], Ibn 'Arabi [w. 638 H], Suhrawardi al-Maqtul [w. 587 H], Shaykh Abdul Qadir al-Jilani [w. $561 \mathrm{H}]$, dan lain-lain. ${ }^{7}$

${ }^{4}$ Khadijah Hammadi, Manhaj al-Imam Fakhruddin al-Razi. hlm. 35-36

${ }^{5}$ Taha Jabir 'Alwani. 2010. Al-Imam AlFakhru Al-Razi wa Musannafatuhu. Qahirah: Dar al-Salam. hlm. 38.

${ }^{6}$ Taha Abdurra'uf Sa'ad, "Muqaddimah Muhaqqiq" dalam Fakhruddin Muhammad ibn 'Umar Al-Razi, Muhassal Afkar alMutaqaddimin wa al-Muta'akkhirin min al'Ulama' wa al-Hukama' wa al-Mutakallimin. Qahirah: Maktabah Kulliyyat Azhariyah, t.th. hlm. 7.

7 Taha Jabir 'Alwani. Al-Imam AlFakhru Al-Razi. hlm. 25.
Seperti akan dipaparkan nanti, watak ilmu kalam dan fiqh di atas mengemuka dalam karya-karyanya. Sejalan dengan itu, para pakar menilai bahwa salah satu orientasi karya AlRazi adalah menolak pemikiran kaum Muktazilah. Perdebatan-perdebatan sengit yang melibatkan Al-Razi ini menimbulkan pro dan kontra di masanya. Bahkan sejarawan mencatat penguburan Al-Razi sengaja dirahasiakan untuk meghindari tindakan yang tidak patut dari lawan-lawan polemiknya. $^{8}$

Menurut Taha Jabir 'Alwani, pola kritik yang dilancarkan Al-Razi mengikuti pola al-Ghazali dalam mengkritik kalangan filosof. Mula-mula menulis tentang hakikat yang benar tentang objek, lalu meluncurkan buku selanjutnya tentang kritik atas pembacaan yang salah tentang objek. Itulah yang dilakukan oleh al-Ghazali melalui Maqasidul Falasifah lalu Tahafut al-Falasifah. ${ }^{9}$

Tidak hanya pola kritik, materimateri dan sistematika ulasan yang digunakan Al-Razi tidak jauh berbeda dari tariqat al-muta'akkhirin pada umumnya, dan al-Ghazali pada khususnya, yaitu berfokus menolak

${ }^{8}$ Hal ini dinyatakan dalam wasiat AlRazi yang dimuat dalam pengantar Nihayat al'Uqul. Baca: Fakhruddin Muhammad ibn 'Umar Al-Razi. 2015. Nihayat al-'Uqul fi Dirayat al-ul. J. I, Bayrut: Dar Dhakha'ir. hlm. 29-30.

9 Dalam Bahasa al-Jabiri, al-Ghazali memberi pukulan telak sehingga Muktazilah tak bisa bangkit lagi [lam taqum ba'dahu qa'imatun]. Muhammad 'Abid al-Jabiri. 1991. al-Turath wa al-Hadathah Dirasat wa Munaqashah. Bayrut: Markaz Dirasat alWihdah al-`Arabiyah. hlm. 170-171. 
pemikiran-pemikiran

muktazilah

dengan 1) memaparkan pandangan lawan polemik; 2) menjelaskan titik kelemahannya; 3) menjelaskan pandangan yang sebenarnya; 4) membangun argumen yang menguatkan dan khas kaum mutaakkhirin; 5) memberi landasan logis (mantiqi) atas bangunan mazhab Syafi'i dan Asy'ari. ${ }^{10}$

Banyaknya pesan yang ingin disampaikan itu membuat karya-karya Al-Razi menjadi karya raksasa. Salah satu di antaranya, Mafatih al-Ghayb disebut oleh Abu Hayyan: "fihi kullu shay'in illa al-tafsir, di dalamnya terdapat semua hal, selain tafsir."11 Namun, Al-Razi cukup sukses mengemban misi penguatan madzhab Ahlussnnah wal Jama'ah. Terbukti, berkat pengajian-pengajian dan karyakaryanya, sebagian besar aliran Syi'ah-Karamiyah di Kota Hirah kembali kepada ajaran Ahlussunnah. Untuk itu, di kota tersebut Al-Razi dikenal sebagai Shaykh al-Islam. Begitu juga ia sukses membawa

10 ariqat al-muta'akkhirin merupakan revolusi metodologis terhadap konsep kalam dan fiqh yang mulanya menggunakan prinsip analogi qiyas ala Mu'tazilah (tariqat almutaqaddimin). Abdurrahman ibn Muhammad Ibn Khaldun. 2004. Muqaddimat Ibn Khaldun. Dimasyq: Dar al-Balkhi. hlm. 205-215.

11 Dengan tegas Abu Hayyan menolak kecenderungan Al-Razi, seperti akan terlihat dalam uraian nanti, yakni mencantumkan kajian dari beragam perspektif, bahkan mengulas perspektif itu sendiri secara teoretik. Jadi, melalui kritik di atas, Abu Hayyan tidak akan mencantumkan uraian detail tentang perspektif ilmu tertentu dalam tafsirnya (al-bahru almuhit) melainkan sekadar kesimpulan atas perspektif itu. Muhammad ibn Yusuf Abu Hayyan al-Andalusi. 1993. al-Bahru al-Muhit. J. I. Bayrut: Dar Kutub Ilmiyah. hlm. 511. tariqat al-muta'akhirin ke puncaknya, sehingga dikenal sebagai al-imam ${ }^{12}$ dalam khazanah ushul fiqh.

\section{Karya-karya Al-Razi}

Seperti pengakuan dalam wasiatnya, Al-Razi menulis buku hampir di setiap cabang ilmu keislaman. Hampir semua karyanya menjadi rujukan utama di masa setelahnya. Seperti al-Mahsul fi Usul al-Fiqh. ${ }^{13}$ Kitab ini menjadi tebal tidak hanya karena merangkum 4 kitab ushul terkemuka, ${ }^{14}$ tetapi juga menampilkan perdebatan teologis dan manthiqi, seperti ulasan tentang qiyas.

Tema qiyas merupakan fokus kajian Al-Razi. Sebab, tema ini produk khas ulama mutakallimin (mazhab

12 Taha Jabir 'Alwani. Al-Imam AlFakhru Al-Razi. hlm. 84-85.

13 Selain merupakan kitab ushul fiqh terlengkap, Abu Hayyan menjadikan al-Mahsul sebagai rujukan tentang teori-teori kebahasaan dalam ushul fiqh seperti ijmal, tabyin, 'umum, khusus, itlaq, taqyid, 'amr dan nahy. $\mathrm{Abu}$ Hayyan al-Andalusi. Al-Bahru al-Muhit. J. I, hlm. 107.

${ }^{14}$ Empat kitab tersebut adalah al-Burhan karya Abu 1-Ma'ali al-Juwayni, al-Mustasfa min ilmi al-Usul karya Abu Hamid al-Ghazali, al-'Ahd karya Qadi Abdul Jabbar dan alMu'tamad fi Usul Fiqh karya Abu Husayn alBasri. Dua karya yang pertama merupakan karya ulama Syafi'iyah-Asy'ariyah, sedang dua yang terakhir dari mazhab Muktazilah. Karakteristik karya ushul dari kedua mazhab ini adalah menampilkan perdebatan teologis dalam ushul fiqh, sehingga dikenal sebagai tariqah mutakallimin. Dan terpenting dicatat bahwa Al-Razi tidak semata-mata merangkum dan menggabungkan keempat kitab tersebut, tetapi sekaligus melanjutkan logikanya lebih radikal. Sehingga catatan-catatan al-Razi menjadi temuan baru tersendiri (mustadrak). Baca: Taha Jabir 'Ulwani, Muqaddimah Muhaqqiq dalam Fakhruddin Muhammad ibn 'Umar Al-Razi. AlMahshul fi Ilmi Usul al-Fiqh. t.tp: Mu'assasah al-Risalah, t.th. hlm. 36. 
Syafi'i dan Asy'ari) dan menjadi muara penggunaan logika teks (al-bayan) dan filsafat (burhan). Dalam pandangan alRazi, sebagian orang, termasuk kelompok yang menerima qiyas, tidak menyadari bahwa dalil yang dikemukakan untuk menguatkan posisi qiyas justru merupakan pondasi yang

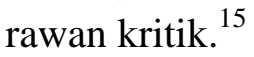

Secara teknis, karya Al-Razi adalah "foto-copy diperbesar" dari karya Imam al-Ghazali. Dalam keduanya memberi pengantar tentang struktur pengetahuan dan penempatan terminologi-terminologi teknis dalam kerangka struktur pengetahuan tersebut. Teknik penulisan ini dapat juga dilihat dari karyanya al-Isharah fi Ilmi alKalam",', dengan menempatkan kualitas ilmu kalam dalam struktur pengetahuan yang logis. ${ }^{16}$ Lebih-lebih dalam Muhassal Afkar al-Mutaqaddimin wal Mutakkhirin, Al-Razi memberi penilaian terhadap keyakinan sebagai objek ilmu kalam dengan pertimbangan logika Aristoteles. ${ }^{17}$

Banyak sekali karya Al-Razi dari beragam disiplin keilmuan. Namun penulis membatasi pada karya-karya yang relevan dengan tulisan ini.

15 Taha Jabir 'Ulwani, Muqaddimah Muhaqqiq, 42

${ }^{16}$ Fakhruddin Muhammad ibn Umar AlRazi. 2009. al-Isyarat fi Ilmi al-kalam. Qahirah: Maktabah Azhariyah lit Turats. hlm. 39-46.

${ }^{17}$ Fakhruddin Muhammad ibn Umar AlRazi. Muhasshal Afkar al-Mutaqaddimin wa alMuta'akhirin min al-Ulama wa al-Hukama' wa al-Mutakallimin. Azhar: Maktabah Kulliyyat alAzhariyah, t.th, hlm. 17-18.

\section{Al-Razi dan Tafsir bil l-Ra'y}

Abdul Mun'im Namir mengategorikan Mafatih al-Ghayb sebagai salah satu jenis tafsir bi l-ra'y. ${ }^{18}$ Bahkan al-Suyuti menyebut Al-Razi sebagai "sahib al-'ulum al- 'aqliyyah."," Identifikasi rasionalitas atau penggunaan ra'y merupakan sesuatu yang wajar bagi ulama mutakhirin sebagaimana digambarkan di atas.

Secara umum, Al-Razi mengaku memilih metode kalam dengan pendekatan filosofis, meski terkadang kesan yang muncul dari karyanya melebihi dari yang seharusnya disampaikan. Seperti dikutip oleh Haji Khalifah, bahwa Al-Razi memasukkan data-data yang tidak berhubungan dengan ayat yang ditafsirkan. ${ }^{20}$

Jika dibanding dengan tafsir bil$r a$ 'y lainnya, terlihat tafsir Al-Razi lebih unggul dari sisi kuantitas. Bahkan, berkenaan dengan QS. Al-Fatihah yang menjadi perhatian penulis, Tafsir alKhozin karya al-Baghdadi hanya menghabiskan 7 halaman, ${ }^{21}$ sama seperti Tafsir al-Baydawi karya Nasiruddin al-Syirazi, yang

${ }^{18}$ Abdul Mun'im Namir. 1985. Ilmu alTafsir Kayfa Nasya'a wa Tathawwara Hatta intaha ila asrina al-hadir. J. I, al-Qahirah: Dar Kutub Islamiyah. hlm. 100.

19 Abdurrahman ibn Abi Bakar Jalaluddin al-Suyuthi. 1974. al-Itqan fi Ulum Al-Qur'an. J. IV, Qahirah: Hay'ah Mishriyah al'Ammah lil Kitab. hlm. 243.

${ }^{20}$ Mushthafa Ibn Abdillah Haji Khalifah. 1756. Kasyf al-Zhunun 'an Asami al-Kutub wa al-Funun. Bayrut: Dar Ihya Turats Araby, t.th. hlm. 408.

21 'Ala'uddin 'Ali ibn Mammad ibn Ibrahim al-Baghdadi. 2004. Lubab al-Ta'wil fi Ma'ani al-Tanzil (Tafsir al-Khozin). Bayrut: Dar al-Kutub al-Ilmiyah. hlm. 15-22. 
menjelaskan Al-Fatihah juga dalam 7 halaman. ${ }^{22}$ Sementara Abu al-Barakat al-Nasafi menjelaskan al-Fatihah dalam 9 halaman melalui Tafsir al-Nasafi. ${ }^{23}$ Jauh melebihi tafsir-tafsir tersebut, AlRazi membahas al-Fatihah dalam 1 jilid kitabnya, setebal 293 halaman.

'Abdul Jawad meringkas metode tafsir Al-Razi ke dalam enam ciri berikut $^{24}$ : Pertama, menampilkan ayat atau surat yang memiliki munasabah dengan ayat yang ditafsirkan. Kedua, menampilkan kajian empirik dan teologis seputar ayat yang dibahas. Ketiga, menentang pemikiran Muktazilah. Keempat, menjelaskan aspek hukum berkenaan dengan ayat yang dibahas. Kelima, menampilkan masalah-masalah yang berkaitan dengan ayat. Keenam, memaparkan aspek kebahasaan, ragam qiraat, yang biasanya digunakan untuk mendalami makna kata per kata.

Seperti dalam penafsiran ayat Thaha $1-8,{ }^{25}$

$$
\begin{aligned}
& \text { طاه (1) مَا أَنْزلْنَا عَلَيْكَ الْقُرْآنَ } \\
& \text { لِتَشْقَى (2) إِلا تَذْكِرَةً لِمَنْ يَخْشَى }
\end{aligned}
$$

22 'Abdullah ibn 'Umar ibn Muhammad al-Baydawi. Anwar al-Tanzil wa Asrar alTa'wil. Bayrut: Dar Ihya' Turath 'Arabi, t.th. hlm. 25-32.

${ }^{23}$ Abu al-Barakat 'Abdullah ibn Ahmad ibn Mahmud al-Nasafi. 1998. Madarik al-Tanzil wa Haqa'iq al-Ta'wil. Bayrut: Dar Kalim Tayyib. hlm. 25-32.

24 Abd al-Jawwad Khalaf Muhammad 'Abd al-Jawad. Madkhal ila al-Tafsir wa 'Ulum Al-Qur'an. Qahirah: Dar Bayan Ara'bi, t.th. hlm. 140.

${ }^{25}$ Fakhruddin Muhammad ibn 'Umar AlRazi. 1981. Mafatih al-Ghayb. J. XXII, Bayrut: Dar al-Fikr. hlm. 2-5.

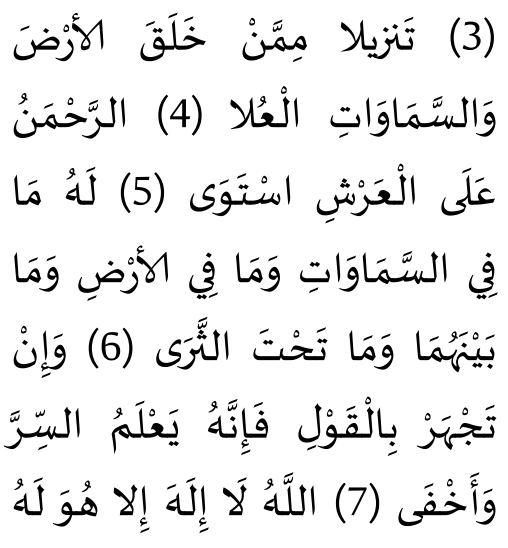

\begin{tabular}{|c|}
\hline $\begin{array}{l}\text { Pertama, } \\
\text { nenampilkan } 5 \text { model } \\
\text { ira'ah dalam membaca } \\
\text { atih surah (Taha). 1) } \\
\text { ira'ah Abu Amr, Ta hi }\end{array}$ \\
\hline
\end{tabular}

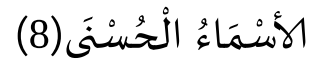

Kedua, Al-Razi menampilkan pendekatan bahasa tentang makna kata tersebut, dengan 1) mengutip Tsa'lab: ta berarti pohon tuba, dan ha berarti hawiyah. Yang kesimpulannya bahwa Allah bersumpah atas nama Surga dan neraka; 2) mengutip Ja'far Al-Sadiq, bahwa ta berarti taharah, dan ha' berarti huda, dengan demikian yang dimaksud taha adalah kesucian ahl bayt dan peran mereka sebagai penunjuk (pasca Rasulullah); 3) mengutip Sa'id ibn Jubayr bahwa taha yang dimaksud sebagai salah satu nama Rasulullah.

Ketiga, Al-Razi menjelaskan sabab nuzul, yang menurutnya ada beberapa versi. 1) bahwa Abu Jahal, Walid ibn Mughirah dan Mat'am ibn 'Adi mengutuk Rasulullah bahwa 
Rasulullah akan celaka jika meninggalkan agama leluhur Arab, dan mereka kukuh dengan kutukan itu meski Rasulullah mengaku risalanyanya sebagai "rahmatan lil 'alamin," maka turunlah ayat ini; 2) ketika Rasulullah melaksanakan Qiyam lail, hingga kakinya bengkak, lalu Malaikat Jibril menegur Rasulullah agar menjaga kesehatan fisik, bahwa Alquran diturunkan agar Rasulullah "menyiksa" diri sendiri, dan turunlah ayat ini [yang berarti: ma anzalnahu lituhlika nafsaka bil 'ibadah].

Keempat, Al-Razi menjelaskan aspek kebahasaan, tentang alasan kata tanzil dibaca nasab, dan mungkin dibaca rafa. Selain itu, menurutnya, peralihan kata ganti (damir) dari orang pertama (na, pada anzalna) menjadi orang ketiga, (huwa muqaddar pada khalaqa) di antaranya karena redaksi pertama dengan format orang pertama, mengisyaratkan keterlibatan Jibril yang menceritakan. Kelima, Al-Razi mengutip hadits tentang keutamaan kalimat tahlil (La Ilaha Illa Allah), dengan tiga silsilah periwayatannya.

Dari paparan tafsir QS. Taha: 18 di atas, terlihat bahwa 6 karakteristik yang disebut di atas tidak semuanya ditemukan dalam tiap penafsiran atau pada tiap rumpun ayat. Bahkan, karakteristik pertama hingga ketiga tidak ditemukan di sana. Namun, pada penafsiran QS. Al-Anbiya: 1-2, Al-Razi menampilkan 1) munasabah dan 2) kritik terhadap kelompok Muktazilah. ${ }^{26}$

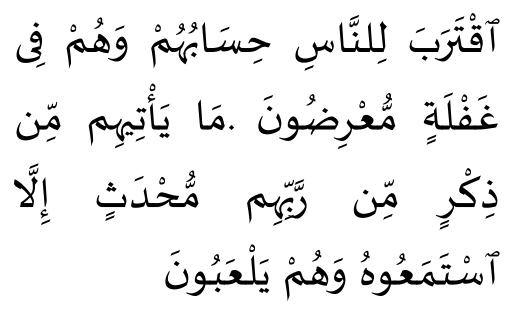

${ }^{26}$ Fakhruddin Muhammad ibn 'Umar AlRazi. Mafatih al-Ghayb. J. XXII, hlm. 139-140.
Fokus perhatian Al-Razi pada rumpun ayat ini adalah kata $d z i k r$, yang digunakan oleh kelompok Muktazilah sebagai dalil kebaruan AlQur'an (Al-Qur'an tidak qadim). Mereka juga mengutip:

$$
\begin{aligned}
& \text { ان هو إلا ذ ذكر للعالمين } \\
& \text { (التكوير: 28)، }
\end{aligned}
$$

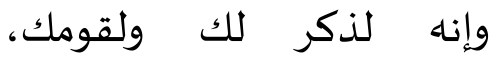

$$
\begin{aligned}
& \text { (الزخرف 44) } \\
& \text { ص، والقرآن ذي الذكر (ص 1- }
\end{aligned}
$$

Kelompok Muktazilah membangun silogisme dari ayat-ayat di atas, bahwa القرآن ذكر، والذكر محدث، فالقرآن محد (Al-Qur'an merupakan dhikr, dhikr itu baru, berarti Al-Qur'an itu baru [tidak qadim]). Dalam pandangan al-Razi, kesimpulan itu salah karena yang dimaksud sebagai dhikr (peringatan) itu merupakan gabungan dari huruf dan suara, berbeda dengan kalamullah secara umum. Kesalahan pemaknaan kata dhikr berisiko pada kesalahan silogisme yang dibangun. Mestinya, menurut al-Razi, silogisme dari ayat-ayat di atas adalah Al-Qur'an adalah dhikr, sebagian dhikr adalah baru, maka Al- 
Qur'an [bisa jadi] tidak termasuk baru. ${ }^{27}$

Pada dasarnya, kesimpulan Muktazilah tentang kebaruan Alquran dilandasi oleh penolakan mereka terhadap sifat Allah, yang dipandang sebagai potensi syirk. Karena Allah Qadim, maka sifat Allah juga Qadim. Dengan demikian ada yang Qadim selain Allah. Simpulnya, meyakini sifat Allah berarti shirk. ${ }^{28}$ Jika Allah adalah bersifat kalam dan mutakallim (berfirman), maka produknya (kalam) dipandang hadits, baru, untuk memurnikan keesaan Allah.

Sampai di sini bisa diperoleh dua simpulan: 1) karakteristik (metode) tafsir Al-Razi tidak dimaksud sebagai metode baku sebagai sistematika tafsirnya, sebagaimana ditemui pada alMaraghi $^{29}$ atau kitab tafsir modern; 2) tafsir Al-Razi lebih ditekankan sebagai, atau paling tidak dipengaruhi oleh kecenderungannya, memberikan pendasaran metodologis bagi bangunan ajaran teologis-yuridis Asy'ariyahSyafi'iyyah. Atau dengan bahasa lain, Al-Razi tidak mengarusutamakan metodologi penafsiran, tetapi menitikberatkan pada materi dan penolakan pada ajaran lawan polemiknya.

\footnotetext{
${ }^{27}$ Fakhruddin Muhammad ibn 'Umar AlRazi. Mafatih al-Ghayb. J. XXII, hlm. 141.

28 Qadi Abdul Jabbar. 1996. Sharh alUsul al-Khamsah. Qahirah: Maktabah Wahbah. hlm. 108-109.

29 Al-Maraghi hampir menjelaskan semua ayat Al-Qur'an dengan dua langkah. yaitu ma'na jumali dan al-idah. Dimana pada bagian kedua ia memberikan beragam pendekatan terhadap kata per kata dalam ayat. Dengan demikian, dua langkah ini merupakan karakteristik sekaligus menjadi sistematika tafsirnya. Baca, Ahmad Mustafa al-Maraghi. 1946. Tafsir al-Maraghi. J. I, Misr: Shirkah wa Matba'ah Mustafa al-Babi al-Halabi. hlm. 4450 .
}

\section{E. Sistematika Tafsir ayat-ayat al- Fatihah}

Seperti dikemukakan sebelumnya, tafsiran QS. Al-Fatihah dalam Mafatih al-Ghayb merupakan tafsiran terpanjang dari keseluruhan kitab tersebut, dan terpanjang untuk QS. Al-Fatihah dibanding dalam karya tafsir lainnya. Salah satu faktornya dinyatakan oleh al-Razi: اعلم انه مر على لساني في بعض الأوقات أن هذه السورة الكريمة ان يستبط من فوائدها ونفائسها عشرة آلاف مسئلة (ketahuilah bahwa pernah aku sebutkan bahwa surat mulia ini [QS. Al-Fatihah] bisa digali faidah dan kandungannya sepuluh ribu permasalahan). Bahkan masing-masing isti'adzah dan basamalah menurutnya mengandung sepuluh ribu masalah. ${ }^{30}$

Meski tidak benar-benar menampilkan puluhan ribu masalah tersebut, Al-Razi mengembangkan seluruh keilmuan yang terkait dengan al-Fatihah sebagaimana terlihat dalam sistematikanya, sebagaimana berikut:
30 Al-Razi menyatakan: yumkinuan yastanbita al-masa'il al-kathirah min alfadh qalilah. Fakhruddin Muhammad ibn 'Umar alRazi. 1981. Mafatih al-Ghayb. J. I, Bayrut: Dar al-Fikr. hlm. 11. 
نهرس الجزء الأول من الفسبر الكبير للامام الفخر الرازي

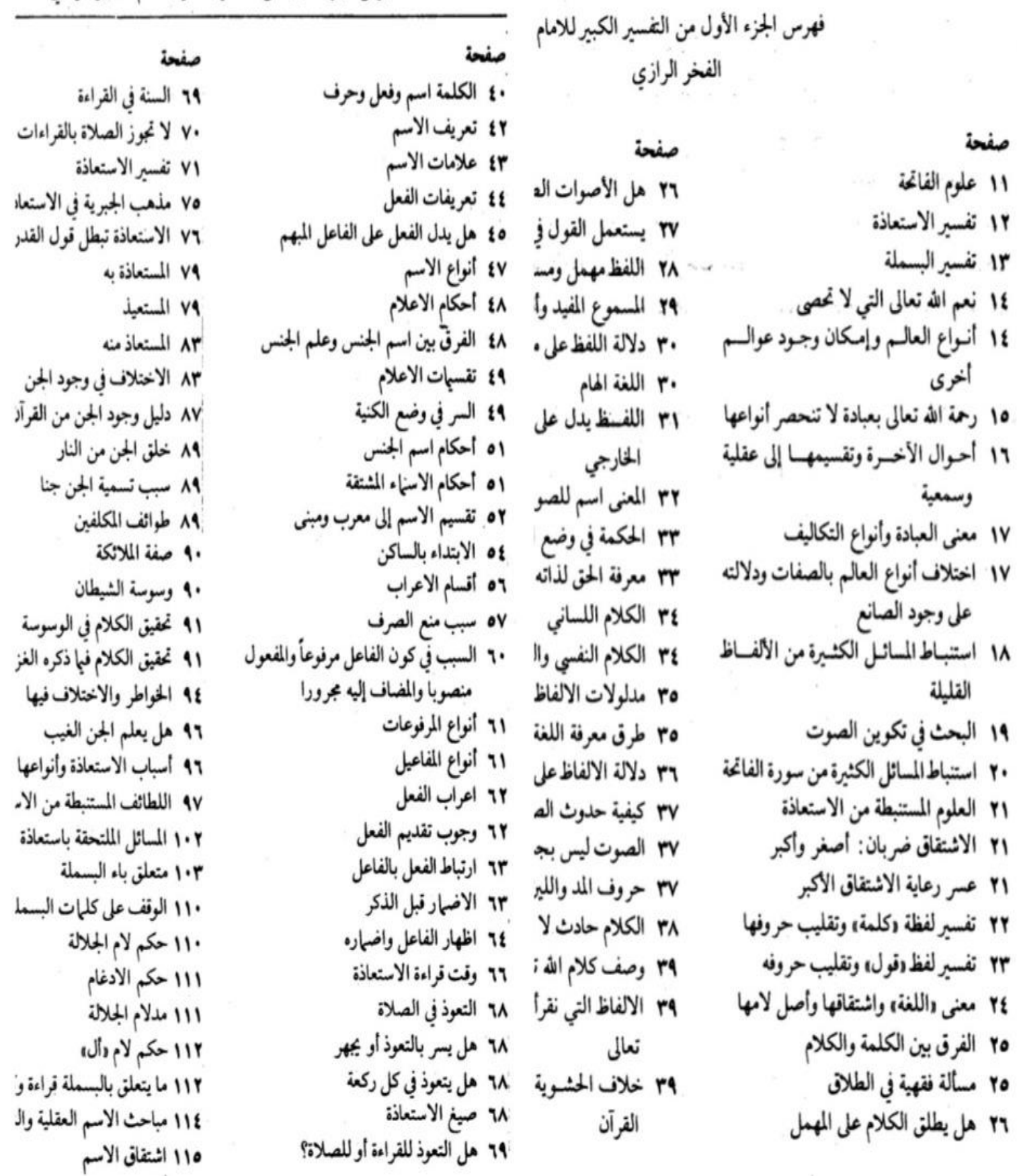


Terlihat pada gambar di atas, ada tiga tahap penafsiran QS. Al-Fatihah: pertama, Al-Razi menjelaskan peta ulum fatihah per kata, kedua, fatihah sebagai kesatuan surat; ketiga, tafsir ijmali berkenaan aspek-aspek eksternal, seperti munasabah dengan akhir QS. AlBaqarah.

\section{Peta 'Ulum Al-Fatihah}

Bagian ini merupakan penjabaran dan rasionalisasi tentang tema-tema yang ia sebut " "ulum al-fatihah."31 اعوذ باله من الثيطان “ Misalnya, pada kata اعوذ اعذ بالهن ia menekankan bahwa (berlindung) mensyaratkan pemahaman tentang hal-hal yang harus dihindari, baik dalam hal keyakinan maupun tindakan. Berkenaan dengan keyakinan yang harus dihindari, terdapat 73 kelompok yang masing-masing memiliki beberapa permasalahan tersendiri. Begitu juga tentang perbuatan yang terlarang, yang meniscayakan kajian-kajian dalam AlQur'an, Sunnah Mutawatir, Sunnah Ahad, Ijma dan qiyas. Menurutnya itu meliputi ribuan kajian. Sehingga ta'awwudz melibatkan puluhan ribu kajian, bahkan lebih.

Pembahasan tentang nama-nama Allah dalam بسم الله الرحمن الرحيم diyakini menyita ribuan pembasahan. Ditambah tentang makna huruf ba' pada kata bismillah. Sementara makna pujian, rasa syukur dan tentang nikmat-nikmat Allah berikut hikmahnya pada kalimat الحمد له meliputi puluhan ribu masalah. Demikian pula pembahasan tentang “alam" pada رب العالمين meliputi kajian tentang benda-benda langit, arsy, kursi, benda-benda bumi seperti gunuh, laut, tanaman, buah-buahan, ibnatang, bunga yang semua itu memerlukan jutaan kajian.

\footnotetext{
${ }^{31}$ Fakhruddin Muhammad ibn 'Umar Al-
} Razi. Mafatih al-Ghayb. J. I, hlm. 11-12.
Pembahasan tentang rahmat Allah (الرحمن الرحيم) sifat Allah sebagai penguasa hari akhir, ciri-ciri hari akhir dan peristiwa yang terjadi di dalamnya dalam (مالك يوم الدين), hakikat ibadah اياك) (إهدنا الصراط المستقيم) (dan hidayah) serta ayat terakhir membutuhkan puluhan ribu pembahasan.

\section{a. Kajian Al-Fatihah sebagai Ayat}

Rincian pembahasan di atas menjadi pembenaran bagi pernyataan Al-Razi bahwa QS. Al-Fatihah membutuhkan puluhan ribu pembahasan. Hal itu didukung oleh karakteristik penafsiran Al-Razi sebagaimana diungkap di atas, sehingga استنباط المسائل الكثيرة “ sangat memungkinkan (menelurkan banyak kajian dari redaksi teks yang ringkas)."

Terungkap pada sistematika Mafatih al-Ghaybjilid I pertama di atas, Al-Razi mengkaji Al-Fatihah dari beragam pendekatan. Ini yang dimaksud oleh Khalil al-Mayis sebagai istitrad, ${ }^{32}$ yaitu menampilkan beberapa pembahasan terkait. Dalam pandangan penulis al-wafi bi al- wafiyat, dengan cara seperti ini Al-Razi membuka ruang kajian baru yang belum pernah ada sebelumnya. ${ }^{33} \quad$ Cabang-cabang pembahasan itu menurutnya dibuat dengan Teknik logika sabr wa taqsim, ${ }^{34}$ sehingga tidak bisa disebut tidak memiliki hubungan dengan ayat yang dibahas.

32 Khalil Mayis, "Muqaddimah Muhaqqiq" dalam Fakhruddin Muhammad ibn 'Umar Al-Razi. Mafatih al-Ghayb., J. I, hlm. 8.

33 Al-Safdi. al-Wafi bi al-Wafiyat. j.II (t.tp: t.p, t.th), 248

34 Muhammad Husayn al-Dhahabi. alTafsir wa al-Mufassirun. J.I, hlm. 294. 
Dari sudut kebahasaan, sedikitnya terdapat 15 pembahasan, antara lain: tentang pengertian dan jenis isytiqaq, perbedaan kalimat dan kalam, dalalat al-alfadh (signifikasi teks), jenis-jenis i'rob, bentuk-bentuk marfu'at dan mafa'il, ${ }^{35}$ i'rab fi'il, ketentuan fi'il harus disebut sebelum fa'il, penggunaan isim damir (kata ganti orang) yang tidak didahului penyebutan kata yang diganti, dan tentang makna huruf $b a$ ' pada kata bismillah. ${ }^{36}$

Sedang dari sudut ilmu tajwid, selain menampilkan ragam qira'ah berkenaan ayat-ayat Al-Fatihah, AlRazi juga membahas tentang hukum lam pada lafaz Allah, hukum idgham, bacaan mad pada lam jalalah, dan hukum lam pada $a l .{ }^{37}$ Sedangkan aspek fiqh juga tidak hanya diketengahkan dalam rangka menafsirkan kata $n a$ 'budu (ibadah) tetapi juga berkenaan dengan soal khilafiyah seperti masalah waktu membaca isti'adzah, apakah ta'awudz harus dibaca pada tiap rakaat, dibaca dengan bersuara atau dalam hati, hal-hal yang disunnahkan dalam qira'ah dan ketidakbolehan membaca Al-Qur'an dengan qira'ah syadhah dalam shalat, ${ }^{38}$

35 Bahkan Al-Razi menjelaskan alasan fa'il itu rofa, dan maf'ul itu nasab. Menurutnya, fa'il atau subjek hanya satu, sementara objek bisa lebih dari satu. Karena jumlah yang banyak itu, maka dipilihlah harakat yang paling ringan, yaitu fathah (nasab). Sementara fa'il yang cuma satu dibaca dammah (harakat paling berat) sehingga terjadi keseimbangan. Fakhruddin Muhammad ibn 'Umar Al-Razi, Mafatih alGhayb. J. I, 60.

${ }^{36}$ Fakhruddin Muhammad ibn 'Umar AlRazi. Mafatih al-Ghayb. J. I, hlm. 40-64.

${ }^{37}$ Fakhruddin Muhammad ibn 'Umar AlRazi. hlm. 110-112.

${ }^{38}$ Al-Razi memperdalam kajian ini pada bagian tafsir internal Al-Fatihah sebanyak 14 bahkan hukum talaq pun menjadi salah satu pembahasan dalam tafsir alfatihah. ${ }^{39}$

Konsentrasi pada kajian ilmu kalam tidak akan lepas dari karya AlRazi. Selain yang include dalam pembahasan ayat, Al-Razi mengangkat beberapa kajian khusus tentang pandangan Jabariyah dan Qadariyah tentang ta'awudz dan dalil tentang keberadaan Jin. Di samping itu, Al-Razi memberi pendekatan rasional tentang makna ta'awudz itu yang ia bagi menjadi musta'adh bih, musta'idh dan musta'adh minhu. Pandangan alGhazali juga menjadi satu tema tersendiri dalam tafsir ini. ${ }^{40}$

Salah satu bentuk kajian teologi Al-Razi yang sangat kental tariqat almuta'akhirin yang logis-ontologis dapat ditemukan pada ulasannya tentang beberapa predikasi terhadap Allah. Relevan dengan 5 nama Allah [Allah, Rabb, Rahman, Rahim, Malik] yang diangkat dalam QS. Al-Fatihah, beberapa kalangan mengembangkan

halaman. Fakhruddin Muhammad ibn 'Umar Al-Razi. Mafatih al-Ghayb. J. I, hlm. 194-208.

39 Sepintas tidak ditemukan korelasi pembahasan talaq dengan kajian surat alFatihah. Sebab, pembahasan ini didasarkan pada ulasannya tentang kalam dalam ilmu nahwu, sebagai kalimat yang mengandung informasi yang jelas, dan bahwa setiap kata mewakili makna sendiri. Dengan demikian, jika seseorang menyatakan kepada istrinya, "jika aku berbicara denganmu, maka kamu tertalaq 3 kali. Menurut ulama Hanafiyah konsekuensi hukumnya adalah talaq ba'in. Sedang menurut al-Razi, mengutip pandangan Zufar, tidak ada talaq, karena kalimat tersebut mengandung unsur pengandaian (bukan kalam dalam ilmu nahwu). Fakhruddin Muhammad ibn 'Umar Al-Razi. Mafatih al-Ghayb. J. I, hlm. 25.

${ }^{40}$ Fakhruddin Muhammad ibn 'Umar AlRazi. Mafatih al-Ghayb, J. I, hlm. 75-91. 
kajian tentang nama-nama Allah, misalnya dzat, nafs, nur, jawhar dan jism. ${ }^{41}$ Berikut kami ulas secara singkat

Istilah yang paling umum digunakan untuk menyebut Allah adalah, dzat. Istilah ini didukung oleh لا تسبوا عليا sejumlah hadits, di antaranya (janganlah kalian mencaci 'Ali [ibn Abi Talib] karena ia sedang tenggelam dalam dzat Allah) dan hadits 'Aisyah yang berbunyi إن من أعظم الناس اجرا الوزير الصالح من امير يطيعه في ذات الله (termasuk orang yang besar pahalanya adalah mentri yang shalih yang patuh kepada seorang pemerintah karena dzat Allah).

Di antara beberapa istilah yang disebut di atas, hanya istilah dzat yang diterima al-Razi. Dia berargumen bahwa penyebutan Allah sebagai dzat tidak bisa dihindari. Karena menyebut sifat tidak mungkin dinisbahkan kepada sifat yang lain. ${ }^{42}$ Oleh karena itu, dibutuhkan sebuah istilah yang bermakna sebuah entitas substasial.

Sementara istilah nafs yang didasarkan pada QS. Al-Ma'idah: 116 dan QS. Ali Imron: 31, begitu juga istilah nur yang didukung oleh QS. AlNur: 35 menurut Al-Razi harus dipahami dalam pengertian dzat di atas,

${ }^{41}$ Fakhruddin Muhammad ibn 'Umar AlRazi. hlm.123-135.

${ }^{42}$ Persoalan sifat tidak menjadi soal lagi bagi Al-Razi, sebab permasalahan ini sudah dituntaskan oleh generasi mutaqaddimin. Bahkan, logikanya, justru sifat membutuhkan dzat, bahwa dzat dan sifat merupakan dua hal yang identik dan tak terpisahkan. Artinya bukan soal sifat itu ada atau tidak, melainkan sifat menjadi argumen tentang adanya dzat. bukan entitas fisik. Lebih-lebih istilah nur dijelaskan dengan ayat mutasyabihat, dan mesti dipahami melalui ayat selanjutnya, yaitu mengidofahkan kata nur pada damir (Allah). Menurut Al-Razi, idafah itu menjadi tanda bahwa yang dimaksud nur bukan Allah, dan bahwa Allah itu bukan cahaya sebagai benda. Sebaliknya, Allah adalah dzat yang memiliki dan menciptakan nur.

Sementara istilah jauhar dan jism adalah istilah yang tidak didukung oleh dalil. Menurut Al-Razi, keduanya ditolak oleh kalangan mutakallimin. Meski dalam khazanah filsafat, jawhar diartikan sebagai entitas yang tidak memiliki bentuk dan tidak membutuhkan tempat. ${ }^{43}$ Lebih-lebih istilah jism yang dipahami oleh kalangan Karamiyah sebagai tajsim, mereka memaksudkan jism sebagai entitas tiga dimensi.

43 Rasionalitas tauhid yang dibangun Muktazilah dengan mengajukan terminologi aljawhar al-fard pada dasarnya dibangun berdasar pada logika qiyas, tentang penglihatan fisis materi, bahwa gajah lebih besar dari semut. Otomatis unsur-unsur pada gajah lebih banyak dibanding unsur semut. Semakin kecil, semakin tak terlihat maka semakin sedikit unsurnya bahkan tak terbagi. Itulah argumentasi pemilihan kata al-jawhar, atom, sebagai lam yatajazza'u (tidak terbagi). Sejalan dengan pemaknaan kaum filosof tentang kata jauhar, sebagai entitas tak berbentuk dan tidak membutuhkan tempat. Namun, unsur terkecil pun memiliki bentuk renik, dan itu tidak pantas diidentikkan dengan Allah. Baca: Muhammad 'Abid al-Jabiri. 1998. al-Kashfu 'an Manahij alAdillah fi 'Aqa'id al-Millah, aw Naqd 'Ilm alKalam Diddan 'ala al-Tarsim al-Aydiyuluji li al-Aqidah wa Difa'an 'an al-Ilm wa Hurriyyati al-Ikhtiyar fi al-Fikr wa al-Fi'l. Bayrut: Markaz Dirasat al-Wihdah al-Arabiyyah. hlm. 21-23. 
Sampai di sini kita bisa menilai bahwa penilaian para ulama tentang tafsir Al-Razi bukan tanpa dasar. AlRazi memuat pandangan-pandangan tentang materi-materi yang sepintas tidak memiliki korelasi yang kuat dengan ayat yang dibahas. Seperti, hubungan tentang kajian nahwu yang detail dengan al-Fatihah, begitu juga kajian talaq dan pembahasan teologisfilosofis. Fihi kullu shay'in illa al-tafsir.

\section{b. Kajian al-Fatihah sebagai surat}

Hal petama yang diulas Al-Razi pada bagian ini adalah menyebut 12 nama surat Al-Fatihah, ${ }^{44}$ di antaranya yang paling populer adalah umm al$k i t a b$, yang berarti intisari. Menurutnya, intisasri Al-Qur'an berkenaan dengan aspek ketuhanan (الحمد للة رب العالمين، الرحمن (الرحيم), hari akhir (مالك يوم الدين), kenabian dan penetapan Qadla-qadar (hingga akhir ayat). Demikian pula persoalan ketuhan juga terangkum dalam surat AlFatihah ini, yaitu pujian dengan lisan, sibuk beribadah dan meminta petunjuk. Sementara penyebutan sab'u al-mathani disebabkan oleh Al-Qur'an terdiri dua bagian, tentang Allah dan hambanya, selalu dibaca saat shalat, dan setiap ayat Al-Fatihah merupakan 1/7 dari Alquran, sehingga yang membacanya berarti membaca keseluruhan Al-Qur'an. Dan salah satu sebab yang populer adalah karena Al-Fatihah diturunkan dua kali, sekali di Mekkah dan sekali di Madinah.

Argumen ini berkenaan dengan bagian selanjutnya, Al-Razi mengungkap beberapa riwayat tentang sabab nuzul. ${ }^{45}$ Menurut riwayat

\footnotetext{
${ }^{44}$ Fakhruddin Muhammad ibn 'Umar AlRazi. Mafatih al-Ghayb. J. I, 179-183.

${ }^{45}$ Fakhruddin Muhammad ibn 'Umar AlRazi. Mafatih al-Ghayb. J. I, hlm. 183-185.
}

pertama, Al-Fatihah diturunkan di Mekkah, bahkan ayat الحمد للّ رب العالمين merupakan salah satu ayat pertama yang turun. Dinyatakan bahwa setelah mendapat ayat tersebut, Rasulullah mengadu kepada Siti Khadijah, dan istrinya inipun berkonsultasi kepada saudaranya, Waraqah ibn Nawfal. Setelah peristiwa Waraqah ini, Malaikat Jibril menyampaikan QS. Al-Fatihah, dimulai dengan bismillah.

Sementara menurut riwayat kedua, Al-Fatihah merupakan Surat Madaniyah. Namun, riwayat ini lemah, sebab sebutan sab'ul matsani ولقد (آناك diungkapkan dalam QS. Al-Hijr آتيناك سبعا من المثاني), yang merupakan surat Makkiyah. Maka tidak mungkin jika AlFatihah belum diturunkan sebelumnya (juga di Mekkah). Sedang riwayat ketiga menyebut Al-Fatihah diturunkan dua kali, di Makkah dan Madinah.

Selebihnya, Al-Razi menampilkan masalah-masalah fiqhiyyah seputar bacaan Al-Fatihah dalam shalat, mengenai hukumnya dengan mencantumkan tafsir ayat قيموا الصلاة sebagai perintah membaca al-Fatihah di dalam shalat, ${ }^{46}$ hadis tentang صلاة الا dan amal para sahabat yang mempraktikkan shalat sesuai tuntunan Rasulullah. Status bismillah sebagai bagian surat atau tidak juga menjadi kajian Al-Razi. Begitu pula tentang terjemahnya, bolehkah dibaca dalam Shalat, sebagai pengganti redaksi dalam bahasa Arab.

\footnotetext{
${ }^{46}$ Bahkan dalam argumen ke sepuluh AlRazi menampilkan hadis yang menegaskan bahwa Al-Fatihah merupakan Surat yang isinya belum pernah disebutkan dalam Taurat dan Injil, dan riwayat tersebut menyatakan bahwa Surat yang dimaksud selalu dibaca dalam shalat. Sehingga shalat identik dengan membaca AlFatihah. Fakhruddin Muhammad ibn 'Umar AlRazi. Mafatih al-Ghayb. J. I, hlm. 197
} 


\section{Tafsir Ayat al-Fatihah}

Berkenaan dengan ayat pertama membuat catatan sebanyak 17 poin, ${ }^{47}$ di antaranya tentang makna kata حمد، مدحح' شكر yang memiliki makna berdekatan. Namun kata yang digunakan di sini adalah alhamdu, yang ia maknai sebagai pujian setelah mendapat nikmat, baik untuk diri sendiri maupun untuk orang lain.

Nikmat itu dibedakan dengan ayat kedua (الرحمن الرحيم) tentang nikmat yang hanya diberikan oleh Allah, ${ }^{48}$ ada juga nikmat yang bisa diperoleh dari manusia. Di sini Al-Razi menampilkan perdebatan kalangan qadariyah dan jabariyah. Apakah iman merupakan nikmat atau bukan. Menurut kelompok qadariyah, iman merupakan prestasi dan buah usaha manusia, karena tidak masuk akal bagi mereka bahwa jika Allah yang memberi nikmat keimanan, mengapa ia menciptakan penghalang (godaan) bagi iman itu. Sementara kelompok jabariyah menegaskan bahwa iman merupakan nikmat tertinggi, sebab jika tidak maka Nama Al-rahman dan Al-rahim lebih identik dengan manusia.

مedang pada ayat ketiga ( مالك يوم (الدين Al-Razi juga menampilkan perbedaan qiraah dalam membaca kata malik. Sekelompok ulama mengutamakan bacaan Panjang (مالك) berarti yang memiliki) ada pula yang mengutamakan bacaan pendek (ملك berarti raja). ${ }^{49}$ Selain menampilkan

\footnotetext{
${ }^{47}$ Fakhruddin Muhammad ibn 'Umar AlRazi. Mafatih al-Ghayb. J. I, hlm. 223-237.

${ }^{48}$ Fakhruddin Muhammad ibn 'Umar AlRazi. Mafatih al-Ghayb. J. I, hlm. 240-246.

49 Argumen yang memilih bacaan Panjang adalah: 1) kelak di hari akhir akan banyak para raja (malik) tapi yang berhak
}

konsekuensi linguistis dari perbedaan makna itu, Al-Razi juga mengembangkan konsep penguasaan ini pada teori kuasa (القدرة) sebagaimana masyhur dalam ilmu kalam tentang perdebatan antara jabariyah dan qadariyah.

Ayat keempat ia penggal menjadi dua bagian, اياك نعبد yang ia tafsirkan dalam konteks keutuhan surat ini. Bahwa ketika Allah menciptakan manusia dari tiada menjadi ada, Dia-lah Ilah. Setelah manusia meng-ada, kebutuhannya bertambah, di situlah Allah berperan sebagai rabb yang Rahman dan Rahim. Berkenaan dengan masa depan, termasuk tentang peristiwa pasca kematian, dengan menyadari bahwa Allah yang memiliki hari pembalasan, maka seorang hamba wajib menyibukkan diri dengan ibadah. ${ }^{50}$ Itulah rahasia bentuk tahsir (spesialisasi) dengan redaksi اياك.

Namun, ibadah saja tidak cukup, bahkan tidak ada jaminan seorang hamba mampu melaksanakan ibadah. Untuk itu penggalan berikutnya ( اياك نستعين) ditafsirkan sebagai berikut: 1) saya beribadah, maka berilah kesempatan untuk

memiliki hari akhir hanya Allah, 2) malik (raja) berarti orang yang membawahi rakyat, sedang pemilik membawahi barang yang dimiliki. Seorang rakyat bisa melepaskan diri dari status sebagai rakyat, sedang barang yang dimiliki tidak bisa demikian. Maka kesimpulannya kekuasaan pemilik lebih absolut. Sementara kelompok ulama yang mengutamakan bacaan pendek (berarti raja) karena dalam sekelompok orang banyak ditemukan pemilik barang, tapi tidak semuanya adalah raja. Maka sang raja cuma satu, itulah Allah. Al-Razi lebih cenderung pada pendapat kedua. Fakhruddin Muhammad ibn 'Umar Al-Razi. Mafatih al-Ghayb. J. I, hlm. 241-242.

${ }^{50}$ Fakhruddin Muhammad ibn 'Umar AlRazi. Mafatih al-Ghayb. J. I, hlm. 246-256. 
menyempurnakannya, hindarkan dari kealpaan atau mati sebelum sempurna ibadah; 2) saya beribadah, namun hati selalu berpaling, maka hadirkanlah hati saya bertawajjuh; 3) saya tidak membutuhkan bantuan siapa pun, kecuali dari Allah. ${ }^{51}$

Yang menarik adalah tafsiran ayat kelima, bahwa jika ayat itu ditafsirkan bahwa seorang yang melakukan ibadah salat meminta petunjuk, akan terjadi tahsil al-hasil (mengadakan sesuatu yang sudah ada.) Sebab seorang yang solat sudah pasti beriman. Seorang mukmin berarti seorang yang telah mendapat petunjuk. Simpulnya orang yang salat sudah pasti mendapat petnunjuk. Lalu untuk apa meminta petunjuk? Al-Razi menjawab: 1) Sirat Mustaqim berarti jalan yang ditempuh oleh orang-orang dahulu yang sanggup menanggung beban berat beribadah; atau 2) jalan tengah antara orang yang berlebihan atau orang yang mengentengkan; 3) berarti palingkan hati kami dari semua hal selain Allah; 4) jalan lurus yang tidak didorong ambisi para pendukung, musuh atau pun setan. ${ }^{52}$

Dan pada ayat terakhir, Al-Razi menolak kecenderungan yang mengidentikkan المغضوب sebagai bangsa Yahudi, dan الضالين sebagai umat Nasrani. Sebab secara kasat Bahasa, al-maghdubi lebih mungkin dipahami sebagai "kelompok orang yang salah dalam

51 Tafsir ketiga ini disarikan dari kisah Nabi Ibrahim yang didatangi oleh Malaikat Jibril saat dibakar oleh Raja Namrud. Jibril bertanya, Wahai Ibrahim, apa yang kamu butuhkan? Nabi Ibrahim menjawab, bantuan dari mu, aku tidak butuh. Sedang kepada Allah, bahkan Ia mengetahui apa yang saya butuhkan. Fakhruddin Muhammad ibn 'Umar Al-Razi. Mafatih al-Ghayb. J. I, hlm. 257.

${ }^{52}$ Fakhruddin Muhammad ibn 'Umar AlRazi. Mafatih al-Ghayb. J. I, hlm. 258-259. praktik kehidupannya," yaitu orangorang kafir. Sedangkan al-Dallin berarti "orang yang salah keyakinannya, seperti orang-orang fasiq." Kesimpulan ini, menurut al-Razi, didukung oleh maknamakna kategori manusia pada awal surat al-Baqarah. ${ }^{53}$

Banyak aspek bahkan terlampau banyak materi yang dikemukakan AlRazi dalam menafsirkan 7 Ayat QS alFatihah ini. Bahkan masih ada satu segmen lagi dari tafsirnya, yaitu tafsir ijmali.

\section{Tafsir Ijmali}

Fase-fase kehidupan yang اياك نعبد dipaparkan dalam penafsiran ayat diulas lebih luas dalam tafsir ijmali. Tujuh Ayat Al-Fatihah juga mencerminkan tujuh perjalanan hidup manusia. Empat tahap pertama adalah fase pengenalan tentang Allah, Malaikat, Kitab dan Rasul. Tahap ini disebut tahap dasar (mabda'); tahap medio (wast) berisi perjalanan fisik dan perjalanan ruhani; dan tahap akhir (ma'ad) berupa fase pulang kepada Allah. ${ }^{54}$

Dari pemetaan ini Al-Razi lalu menghubungkan ketujuh ayat AlFatihah ini dengan akhir Surat AlBaqarah, sebagai 7 doa terkait dengan fase-fase di atas. Pertama ربنا لا تؤاخذنا إن نسينا او أخطأنا selalu ingat, berdzikir kepada Allah, sangat relevan dengan penyebutan tiga asma Allah pada ayat pertama Al-

${ }^{53}$ Yang dimaksud kategori manusia pada surat al-Baqarah adalah orang bertakwa (almuttaqin), orang kafir (alladhina kafaru), dan orang-orang munafik (wa mina al-nasi man yaqulu amanna). Fakhruddin Muhammad ibn 'Umar Al-Razi. Mafatih al-Ghayb. J. I, hlm. 264-265.

${ }^{54}$ Fakhruddin Muhammad ibn 'Umar AlRazi. Mafatih al-Ghayb. J. I, hlm. 268-269. 
Fatihah (Allah, Al-Rahman dan AlRahim). Sementara kedua, ربنا ولا تحمل علينا

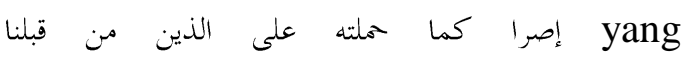
menekankan kelalaian manusia, dan itu terkait dengan "kewajiban" untuk memuji Allah (الحمد للّ رب العالمين).

Ketiga, ربنا ولا تحملنا ما لاطاقة لنا به yang didasarkan pada sifat Rahman dan Rahim Allah. Keempat, واعف عنا yang berkenaan dengan pengampunan di hari akhir dengan ayat مالك يوم الدين. Kelima, doa gihubungkan dengan pernyataan pengabdian dan permohonan taufiq (اياك نعبد واياك نستعين) sedang yang keenam, وارممن واكن dengan memohon hidayah pada ayat وارحنا الصراط المستقيم.

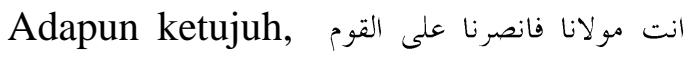
berhubungan erat dengan status

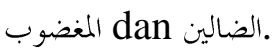

Gambaran perjalanan spiritual inilah yang menjadi kunci shalat sebagai mi'raj al-mu'minin. Al-Razi menempatkannya sebagai asrar aqliyyah $^{55}$ dari QS. Al-Fatihah.

Sampai di sini cukup terlihat karakter tariqat al-muta'akhirin. Pertama, ulasan teologi dan kebahasaan dalam tafsir ini diibngkai secara logisrasional. Kedua, peleburan epistemologis antara bayani dan irfani mengalir tanpa kontras yang mencolok. ${ }^{56}$ Karakteristik kedua ini

55 Bandingkan dengan penggunaan terminologi sirr, asrar dalam kitab Ihya 'Ulumiddin karya Imam al-Ghazali, seperti Asrar al-Taharah, Asrar al-Salat, dan sebagainya. Baca: Muhammad Abu Hamid alGhazali. 1971. Ihya' 'Ulumiddin. Bayrut: Dar Kutub Ilmiyyah, hlm. 121 dan 140.

${ }^{56}$ Seperti dinyatakan oleh Taha Jabir Al'Ulwani, Al-Razi memiliki ketertarikan pada dunia sufi, meski ia tidak mau tenggelam dalam asketisme para sufi. Diriwayatkan bahwa ia meminta gurunya Najmuddin al-Kubra juga bisa ditemukan dalam karya-karya al-Ghazali, peletak pondasi tariqat almuta'akhirin.

\section{F. Menjawab Muktazilah}

Aspek terakhir yang menjadi karakter tafsir Al-Razi adalah kutipannya dari pemikiran Muktazilah. Sedari awal, Al-Razi menegaskan bahwa ia merangkum pemikiran kalam Asy'ariyah-Muktazilah melalui karyakarya Qadi 'Abdul Jabbar dan Imam alGhazali. Artinya, kutipan-kutipan dari kalangan muktazilah memang jadi salah satu karakter utama karya-karyanya. ${ }^{57}$

Berkenaan dengan tafsir, ada dua model kutipan Al-Razi. Pertama, ia hanya menyebutkan nama alMuktazilah. Misalnya dalam

mengajarinya ma'rifat. Sang guru memberi syarat Al-Razi meninggalkan pola hidupnya saat itu. Al-Razi menolak bahwa dia tidak bisa memenuhinya. Namun terlihat dari beberapa pandangannya yang bersifat spiritual dan asketis seperti pada tafsir ini. Taha Jabir 'Ulwani. alImam Fakhruddin Al-Razi. hlm. 9.

${ }^{57}$ Seperti para ulama pendahulunya dari kalangan Asya'irah, misi karya-karya mereka adalah untuk menjelaskan keterbatasan akal manusia untuk menjangkau hikmah $A f^{\prime}$ al Allah, di mana Muktazilah merupakan kelompok yang secara radikal menempatkan akal sebagai kunci memahami segalanya, termasuk tentang Allah (baca catatan kaki nomor 62 makalah ini). Bedanya, generasi awal Asya'irah (terhitung dari Imam Abu Hasan al-Asy'ari) menempatkan akal dan nash pada posisi sejajar, dalam pengertian bahwa Asya'irah tidak membunuh potensi rasionalitas manusia, tetapi nash berperan sebagai acuan utama. Abu Bakar alBaqillani membuka fase kedua dengan menempatkan logika sebagai perangkat memahami nash. Begitu pula Abu al-Ma'ali alJuwayni. Sementara al-Ghazali yang menuntaskan fase kedua ini dengan membuat pendasaran manthiq, menggantikan qiyas ala Muktazilah. Fase Al-Razi menjadi puncak dari pertumbuhan Asya'irah. Khadijah Hammadi Abdallah. Manhaj al-Imam Fakhruddin Al-Razi. hlm. 41-42 


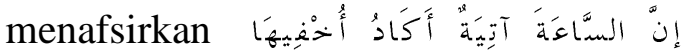

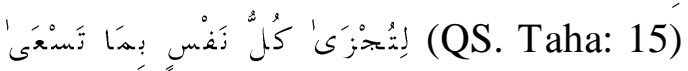
Al-Razi tegas menyebut: "menurut Muktazilah," atau "Muktazilah membangun argumentasi" bahwa ayat di atas mengisyaratkan bahwa perbuatan manusia merupakan perbuatannya sendiri, terlepas dari keinginan Allah. ${ }^{58}$

Kedua, Al-Razi mengutip karya seorang mufassir Muktazilah, alقال صاحب Zamakhshari, dengan menyebut الكشاف, atau al-Zajjaj dan Qadi Abdul Jabbar, misalnya pada penafsiran QS. Al-Anbiya' ayat 1-3. ${ }^{59}$

Kecenderungan seperti ini yang meninggalkan kesan bahwa Al-Razi beralih dari madzhab Asy'ariyah ke Muktzilah. Sebab, kutipan-kutipan itu dibahas secara tidak memadai. ${ }^{60}$ Hanya saja perlu ditegaskan bahwa, 1) fokus perhatian Al-Razi adalah menguatkan argumen Asy'ariyah dengan memberi catatan kritis pada pandanganpandangan lawannya; 2) sebagian tokoh Muktazilah generasi akhir, seperti Qadi Abdul Jabbar dan Husayn al-Basri, memiliki pandangan yang sama dengan kalangan Asy'ariyah, seperti alGhazali. $^{61}$

\footnotetext{
${ }^{58}$ Fakhruddin Muhammad ibn 'Umar AlRazi. Mafatih al-Ghayb, J. XXII. hlm. 22-23.

${ }^{59}$ Fakhruddin Muhammad ibn 'Umar AlRazi. Mafatih al-Ghayb. J. XXII. hlm. 139.

${ }^{60}$ Sulayman ibn Abdi al-Qawi al-Tufi. 1977. al-Iksir fi Ilmi al-Tafsir. al-Qahirah: Maktabah al-Adab. hlm. 55

${ }^{61}$ Dalam hal tajsim (menganggap Allah memiliki fisik seperti halnya manusia) Muktazilah menolak menggunakan qiyas: entitas ghaib dapat dipahami sebagaimana entitas lahir. Tapi berkenaan dengan af'al Allah, Muktazilah menggunakan qiyas. Bahkan mereka meyakini, bahwa Allah wajib berbuat adil, sebagaimana manusia juga harus berbuat adil. Tentang penggunaan teori qiyas ini, Qadi Abdul Jabbar sependapat dengan generasi pendahulunya seperti Abu 'Ali al-Jubba'i. Khadijah Hammadi Abdallah. Manhaj al-Imam Fakhruddin Al-Razi. hlm. 149-150.
}

Seperti tentang penolakan terhadap teori بطلان الدليل يؤذن ببطلان المدلول, bahwa ketiadaan dalil berkonsekuensi pada kesimpulan tidak adanya madlul. Al-Razi menolak teori ini sebagai buah pikiran Abu Bakar al-Baqillani (dari Asy'ariyyah) dan menyematkannya pada generasi awal Muktazilah. Dalam rangka menolak teori tersebut, Al-Razi mengutip al-Juwayni, al-Ghazali, juga dua ulama Muktazilah seperti Qadi Abdul Jabbar dan Husayn al-Basri. ${ }^{62}$

Sebagai catatan akhir, penulis berkesimpulan bahwa tugas utama AlRazi dalam bingkai madzhabnya adalah memperkaya bangunan atas Madzhab Asy'ariyah dengan kajian filsafat dan ketuhanan, tanpa terjebak dalam mistisisme ala Ibn Sina. Sebab bangunan logika sudah terbangun di tangan al-Ghazali. ${ }^{63}$

Memang tidak bisa dimungkiri, karakteristik pemikiran dan penafsiran Al-Razi memberikan kajian yang sangat luas. Namun, keluasan itu menghilangkan fokus kajiannya. Fihi kullu shay'in illa al-tafsir.

\section{Daftar Pustaka}

Abdallah, Khadijah Hammadi. 2012. Manhaj al-Imam Fakhruddin AlRazi, Bayna al-Asya'irah wa alMu'tazilah. Bayrut: Dar alNawadir.

Al-'Alwani, Taha Jabir. 2010. Al-Imam Al-Fakhru Al-Razi wa Musannafatuhu. Qahirah: Dar alSalam.

Al-Baghdadi, Ala'uddin 'Ali ibn Muhammad ibn Ibrahim. 2004.

${ }^{62}$ Khadijah Hammadi Abdallah. Manhaj al-Imam Fakhruddin Al-Razi. hlm. 175

${ }^{63}$ Al-Jabiri. Al-Turath wa al-Hadathah. hlm. 171. 
Lubab al-Ta'wil fi Ma'ani alTanzil (Tafsir al-Khozin). Bayrut: Dar al-Kutub al-Ilmiyyah.

Al-Baydawi, Abdullah ibn 'Umar ibn Muhammad. Anwar al-Tanzil wa Asrar al-Ta'wil. Bayrut: Dar Ihya' Turath Arabi, t.th

Al-Dhahabi, Muhammad Husayn. 2010. al-Tafsir wa al-Mufassirun. J. I, Kuwayt: Dar al-Nawadir.

Al-Ghazali, Muhammad Abu Hamid. 1971. Ihya' 'Ulumiddin. Bayrut: Dar Kutub Ilmiyah.

Al-Jabiri, Muhammad 'Abid. 1998. alKashfu 'an Manahij al-Adillah fi 'Aqa'id al-Millah, aw Naqd 'Ilm al-Kalam Diddan 'ala al-Tarsim al-Aydiyuluji li al-'Aqidah wa Difa'an 'an al-Ilm wa Hurriyyati al-Ikhtiyar fi al-Fikr wa al-Fi'l. Bayrut: Markaz Dirasat alWihdah al-'Arabiyyah.

Al-Jabiri, Muhammad 'Abid. 1991. alTurath wa al-Hadathah Dirasat wa Munaqashah. Bayrut: Markaz Dirasat al-Wihdah al-'Arabiyah.

Al-Jabiri, Muhammad 'Abid. 1993. Nahnu wa 1-Turath Qira'at Mu'asirah fi Turathina al-Falsafi. Bayrut: Markaz Thaqafi 'Arabi.

Al-Maraghi, Ahmad Mustafa. 1946. Tafsir al-Maraghi. J. I, Misr: Shirkah wa Matba'ah Mustafa alBabi al-Halabi.

Al-Nasafi, Abu al-Barakat Abdullah ibn Ahmad ibn Mahmud. 1998. Madarik al-Tanzil wa Haqa'iq alTa'wil. Bayrut: Dar Kalim Tayyib.

Al-Razi, Fakhruddin Muhammad ibn 'Umar. 2009. al-Isharat fi Ilmi al-
Kalam. Qahirah: Maktabah Azhariyah li al-Turath.

Al-Razi, Fakhruddin Muhammad ibn 'Umar. Al-Mahsul fi Ilmi Usul alFiqh. t.tp: Mu'assasah al-Risalah, t.th.

Al-Razi, Fakhruddin Muhammad ibn 'Umar. 1981. Mafatih al-Ghayb. J. I, Bayrut: Dar al-Fikr.

Al-Razi, Fakhruddin Muhammad ibn 'Umar. 1981. Mafatih al-Ghayb. J. XXII, Bayrut: Dar al-Fikr.

Al-Razi, Fakhruddin Muhammad ibn 'Umar. Muhassal Afkar alMutaqaddimin wa alMuta'akkhirin min al-'Ulama wa al-Hukama' wa al-Mutakallimin. Qahirah: Maktabah Kulliyyat Azhariyah, t.th.

Al-Razi, Fakhruddin Muhammad ibn 'Umar. 2015. Nihayat al-'Uqul fi Dirayat al-Usul. J. I, Bayrut: Dar Dzakha'ir.

Al-Safdi. al-Wafi bi al-Wafiyat. J. II, t.tp: t.p, t.th

Al-Suyuti, Abdurrahman ibn Abi Bakar Jalaluddin. 1974. al-Itqan fi 'Ulum Al-Qur'an. J. IV, Qahirah: Hay'ah Misriyah al-'Ammah li alKitab.

Al-Tufi, Sulayman ibn Abdil Qawi. 1977. al-Iksir fi Ilmi al-Tafsir. alQahirah: Maktabah al-Adab. hlm. 55

Hayyan, Muhammad ibn Yusuf Abu. 1993. al-Bahrul Muhit. J. I Bayrut: Dar Kutub Ilmiyah.

Jabbar, Qadi Abdul. 1996. Sharh alUsul al-Khamsah. Qahirah: Maktabah Wahbah. 
Jawad, Abdul Jawad Khalaf Muhammad Abdul. Madkhal ila al-Tafsir wa 'Ulumil Qur'an. Qahirah: Dar Bayan Arabi, t.th.

Khaldun, Abdurrahman ibn Muhammad Ibn. 2004. Muqaddimah Ibn Khaldun. Dimasyq: Dar al-Balkhi. Khalifah, Mustafa Ibn Abdillah Haji. Kashf al-Dhunun 'an Asami al-
Kutub wa al-Funun. Bayrut: Dar Ihya Turath Arabi, t.th.

Namir, Abdul Mun'im. 1985. Ilmu alTafsir Kayfa Nasya'a wa Tatawwara Hatta intaha ila 'Asrina al-Hadir. J. I, al-Qahirah: Dar Kutub Islamiyah. 